ECREG STUDIES

Vol. 10, No. 1, 2017

www.ers.edu.pl

PDF OPEN ACCESS

eISSN 2451-182X
ECONOMIC AND REGIONAL STUDIES

STUDIA EKONOMICZNE I REGIONALNE

ISSN 2083-3725
Volume 10, No. 1, 2017
Authors' contribution/

Wkład autorów:

A. Zaplanowanie badań/

Study design

B. Zebranie danych/

Data collection

C. Analiza statystyczna/

Statistical analysis

D. Interpretacja danych/

Data interpretation

E. Przygotowanie tekstu/

Manuscript preparation

F. Opracowanie

piśmiennictwa/

Literature search

G. Pozyskanie funduszy/

Funds collection

\section{AGRICULTURAL ADVISORY SERVICES IN EASTERN MAZOVIA IN THE ACTIVITY OF THE MAZOVIAN AGRICULTURAL ADVISORY CENTRE}

\section{ROLNICZE USŁUGI DORADCZE NA WSCHODNIM MAZOWSZU W DZIAŁALNOŚCI MAZOWIECKIEGO OŚRODKA DORADZTWA ROLNICZEGO}

\author{
${\text { Marek Niewęgłowski }{ }^{(\mathrm{A}, \mathrm{B}, \mathrm{C}, \mathrm{D}, \mathrm{E}, \mathrm{F})} \text {, Joanna Pielech }}^{(\mathrm{A}, \mathrm{B}, \mathrm{C}, \mathrm{D}, \mathrm{E}, \mathrm{F})}$ \\ University of Natural Sciences and Humanities in Siedlce \\ Uniwersytet Przyrodniczo-Humanistyczny w Siedlcach
}

Niewęgłowski M., Pielech J. (2017), Agricultural advisory services in eastern Mazovia in the activity of the Mazovian Agricultural Advisory Centre/ Rolnicze usługi doradcze na wschodnim Mazowszu w działalności Mazowieckiego Ośrodka Doradztwa Rolniczego. Economic and Regional Studies. Vol. 10, No. 1, pp. 85-99. https://doi.org/10.2478/ers-2017-0007

\section{Summary}

Subject and purpose of work: The study presents the effects of agricultural advisory services in the eastern part of Mazovia. The effect of advisory work was the number of services provided by advisers over a three-year-long period of their work. The state institution providing advisory services for farmers in this area is the Warsaw-based Mazovian Agricultural Advisory Centre (MAAC) with a Branch Office in Siedlce. The main objective of the conducted research was to assess the performance of agricultural advisers within six counties: Siedlce, Węgrów, Garwolin, Łosice, Sokołów and Mińsk, located in the eastern part of Mazovian (pol. Mazowieckie) Province.

Materials and methods: The activity of the Siedlce Branch was analysed during the years 2012-2014. Particular attention was paid to the distribution and availability of services to farmers. This study was prepared on the basis of an analysis of available internal documents from MAAC and the literature on this field.

Results: Based on the performed studies, it was found that agricultural advisory services play a very important role in the adaptation of farms to changing environmental conditions.

Conclusions: Nowadays, in the era of globalisation and integration farmers face new challenges, which would be difficult to meet without an efficient agricultural advisory system.

Keywords: agricultural advisory services, Siedlce region, Mazovian Agricultural Advisory Centre, Siedlce Branch

\section{Streszczenie}

Przedmiot i cel pracy: W opracowaniu przedstawiono efekty rolniczych usług doradczych we wschodniej części Mazowsza. Efektem pracy doradczej była ilość wykonanych przez doradców usług na przestrzeni ich trzyletniej pracy. Instytucją państwową, która świadczy usługi doradcze dla rolników na tym terenie jest Mazowiecki Ośrodek Doradztwa Rolniczego (MODR) z siedzibą w Warszawie Oddział Siedlce. Głównym celem przeprowadzonego badania było dokonanie oceny pracy doradców rolniczych na terenie sześciu powiatów: siedleckiego, węgrowskiego, garwolińskiego, łosickiego, sokołowskiego i mińskiego położonych we wschodniej części województwa mazowieckiego.

Materiały i metody: Przeanalizowano działalność Oddziału Siedlce w latach 2012 - 2014. Szczególną uwagę zwrócono na rozmieszczenie i dostępność usług dla rolników. Opracowanie powstało na podstawie analizy dostępnych dokumentów wewnętrznych MODR oraz literatury przedmiotu.

Wyniki: Na podstawie przeprowadzonych badań stwierdzono, że doradztwo rolnicze spełnia bardzo ważną funkcję w dostosowaniu gospodarstw do zmieniających się warunków otoczenia.

Wnioski: W obecnych czasach w dobie globalizacji i integracji rolnicy stają przed nowymi wyzwaniami, którym trudno byłoby sprostać bez sprawnego systemu doradztwa rolniczego.

Słowa kluczowe: rolnicze usługi doradcze, region siedlecki, Mazowiecki Ośrodek Doradztwa Rolniczego, Oddział Siedlce

Address for correspondence/ Adres korespondencyjny: dr Marek Niewęgłowski, Mazowiecki Ośrodek Doradztwa Rolniczego, ul. Czereśniowa 98, 02-456 Warszawa, Uniwersytet Przyrodniczo-Humanistyczny w Siedlcach, Zakład Ekonomiki Rolnictwa i Agrobiznesu, ul. Prusa 14, 08-110 Siedlce, Polska; tel. +48 2564312 90, e-mail: nieweglowskim@uph.edu.pl; mgr Joanna Pielech, Mazowiecki Ośrodek Doradztwa Rolniczego, ul. Czereśniowa 98, 02-456 Warszawa, Uniwersytet Przyrodniczo-Humanistyczny w Siedlcach, Katedra Gleboznawstwa i Chemii Rolniczej, ul. Prusa 14, 08-110 Siedlce, Polska; tel. +48 25) 64312 91, e-mail: joanna.pielech@gazeta.pl

Journal indexed in/ Czasopismo indeksowane w: AgEcon Search, AGRO, BazEkon, Index Copernicus Journal Master List, ICV 2015: 81,26; Polish Ministry of Science and Higher Education 2016: 9 points/ AgEcon Search, AGRO, BazEkon, Index Copernicus Journal Master List ICV 2015: 81,26; Ministerstwie Nauki i Szkolnictwa Wyższego 2016: 9 punktów. Copyright: (C) 2016 Pope John Paul II State School of Higher Education in Biała Podlaska, Marek Niewęgłowski, Joanna Pielech. All articles are distributed under the terms of the Creative Commons Attribution-NonCommercial-ShareAlike 4.0 International (CC BY-NC-SA 4.0) License (http://creativecommons.org/licenses/bync-sa/4.0/), allowing third parties to copy and redistribute the material in any medium or format and to remix, transform, and build upon the material, provided the original work is properly cited and states its license. 


\section{Introduction}

According to the definition, agricultural advisory service is an educational activity, which consists in self-motivation and intentional partnership cooperation between a farmer and agricultural adviser, which aims at solving their problems (Grzelak 2009, Nowogródzka 2009).

Agricultural advisory centres, whose mission is to support farmers and Polish agriculture in the process of changes taking place in rural areas, play the leading role in the agricultural advisory system in Poland. Particular attention is paid to a large-scale training activity of Agricultural Advisory Centres, assistance in developing business plans, filling out application forms as well as drafting requests. The work of advisers to a very large extent facilitates dealing with complex procedures for farmers in order to access the EU funds and grants. It is a very responsible and difficult task, given the economic sanctions imposed by the EU (Kania 2006, Kania 2006a, Kania 2006b, Kujawiński 2003).

The staff employed by the centres of agricultural advisory services are qualified advisory personnel, mostly with a higher education level. They continually improve their qualifications through participation in courses, workshops or postgraduate studies (Toruński 2011).

Agricultural Advisory Centres perform statutory and commercial activities. The former consists in organising regular stationary and field courses, giving presentations, holding shows or giving advice. The latter one involves drawing up investment plans, applications for various types of subsidies and agricultural refinancing or organising agrichemical courses (Matuszak 2003).

The search for the functioning model of agricultural advisory centres has been going on in Poland for the last several years. Currently, it fulfils three main functions: educational, advisory and informative. The implementation of these functions has enabled advisory centres to act as a liaison between agriculture and its environment in terms of: economics, technology, legal and political issues, and international approach. Much of the focus is on modern advisory functions i.e.: stimulating the diffusion of innovation and entrepreneurship, which should lead to a multi-functional and sustainable rural development. Continuously introduced changes in regulations limit subsidies allocated to the operations of agricultural advisory centres. An effective and modern advisory system must meet the needs of its participants and customers. It should be accomplished by: close links between advisory services and science, efficient functioning with limited resources by adapting the system to the existing organisational and economic realities within agriculture and by transferring some of the costs of services to clients, being flexible - it means being able to develop and transform to address new requirements of the economy with particular focus on the development of agriculture and rural areas (Staniszewski 2014).

\section{Wstęp}

Doradztwo rolnicze według definicji jest działalnością edukacyjną, która polega na automotywowaniu oraz intencjonalnym, partnerskim współdziałaniu w relacji rolnik - doradca rolniczy, zmierzającym do rozwiązania jego problemów (Grzelak 2009, Nowogródzka 2009).

Wiodącą rolę $\mathrm{w}$ systemie doradztwa rolniczego w Polsce odgrywają ośrodki doradztwa rolniczego, których zadaniem jest wspieranie rolników i polskiego rolnictwa w przemianach jakie zachodzą na obszarach wiejskich. Szczególną uwage zwraca zakrojona na szeroką skalę działalność szkoleniowa ODR-ów, pomoc przy opracowywaniu biznesplanów inwestycyjnych, przy wypełnianiu wniosków jak również pisaniu podań. Praca doradców w bardzo dużym stopniu ułatwia rolnikom pokonywanie skomplikowanych procedur w sięganiu po środki unijne i dotacje. Jest to bardzo odpowiedzialne i trudne zadanie zważywszy na nakładane przez UE sankcje ekonomiczne i gospodarcze (Kania 2006, Kania 2006a, Kania 2006b, Kujawiński 2003).

Osoby zatrudnione w ośrodkach doradztwa rolniczego to wykwalifikowana kadra doradcza posiadająca w większości wyższe wykształcenie, ustawicznie podnosząca swoje kwalifikacje przez udział w kursach, szkoleniach, studiach podyplomowych (Toruński 2011).

Ośrodki Doradztwa Rolniczego realizują działalność statutową i komercyjną. Pierwsza polega na organizowaniu szkoleń stacjonarnych i wyjazdowych, prowadzeniu demonstracji, pokazów, udzielaniu porad. Druga, natomiast polega na sporządzaniu planów inwestycji, wniosków o różnego rodzaju dopłaty oraz dofinansowania rolnicze, organizowaniu kursów chemizacyjnych (Matuszak 2003).

Od kilku lat w Polsce poszukiwany jest model funkcjonowania doradztwa rolniczego. Obecnie spełnia ono trzy główne funkcje, czyli: edukacyjną, doradczą oraz informacyjną. Realizacja tych funkcji w głównej mierze przyczynia się do pełnienia przez ośrodki doradztwa roli łącznika między rolnictwem, a jego otoczeniem $w$ ujęciach: ekonomicznym, technicznym, prawno-politycznym i międzynarodowym. Najsilniej akcentowane są nowoczesne funkcje doradztwa tj.: pobudzanie dyfuzji innowacji oraz przedsiębiorczości, które powinny prowadzić do wielofunkcyjnego oraz zrównoważonego rozwoju obszarów wiejskich. Kolejne zmiany przepisów ograniczają subwencje przeznaczane na działalność ośrodków doradztwa rolniczego. Efektywny i nowoczesny system doradztwa musi zaspokajać potrzeby odbiorców i uczestników systemu. Powinno się to odbywać przez: ścisłe powiązanie doradztwa z nauką, sprawne funkcjonowanie przy ograniczonych środkach przez dostosowanie systemu do istniejących realiów organizacyjnych i ekonomicznych w rolnictwie oraz przeniesienie niektórych kosztów usług na klientów, bycie elastycznym - czyli zdolnym do rozwoju i przeobrażeń w kierunku nowych potrzeb gospodarki, ze szczególnym uwzględnieniem rozwoju rolnictwa i obszarów wiejskich (Staniszewski 2014). 


\section{The objective, material and methods}

The aim of the study was to present the effects of agricultural advisers' work within the area of eastern Mazovia. The effect of advisory work is the number of services provided by advisers. The state institution providing advisory services for farmers in the area of eastern Mazovia is the Warsaw-based Mazovian Agricultural Advisory Centre (MAAC) with a Branch Office in Siedlce. The analysis of the provided advisory services covered six counties: Siedlce, Węgrów, Garwolin, Łosice, Sokołów and Mińsk. The data on a three-year-long period of advisers' activity were input for the analysis. Particular attention was paid to the distribution and availability of services to farmers. The study was prepared on the basis of a review of available internal documents from MAAC and the literature dealing with this field.

\section{The outcome of the research}

In recent years, measures have been taken in Poland in order to streamline the organisational structures of agricultural advisory services. Currently, the functioning of the state-funded consulting institutions is regulated by the Act on Agricultural Advisory Bodies established by the Parliament of 22 October 2004. The provisions of this Act came into force on 01.01.2005 and they reformed agricultural advisory services and partly limited the occurrence of competence conflicts and task duplication among the bodies offering agricultural advisory services (The Act on Agricultural Advisory Bodies of 22 October 2004 (Journal of Laws of 2013, item 474, as amended).

In the Mazovian, Agricultural Advisory Centre three organisational levels are distinguished: provincial (referring to the entire province), and the levels of local branches and outposts. The overall functioning of the MAAC in Warsaw is the responsibility of the Director, who runs the Regional Centre with the help of two deputies, the chief accountant, heads of Local Branches and managers of organisational units. The second level consists of Local Branches (The organisational regulations of the Mazovian Agricultural Advisory Centre in Warsaw). The Branch Office in Siedlce is one of six MAAC local branches covering the eastern part of Mazovian province, the area of six counties: Siedlce, Węgrów, Garwolin, Łosice, Sokołów and Mińsk, where 59 communes are located. There are 1498 villages and over 68 thousand farms altogether on the area covered by the Siedlce Branch.

During the years 2012-2014, the employees of the Siedlce Branch have continued to implement the objectives of the National Rural Development Programme coordinated with the National Development Strategy for the years 2007-2013. Polish presence in the European Union and the processes of adjustment conducted in agriculture have directed the agricultural advisory services towards measures focusing on the issues related to the process of adjusting the conditions of agricultural production to

\section{Cel, materiał i metody}

Celem opracowania było przedstawienie efektów pracy doradców rolniczych na terenie wschodniego Mazowsza. Efektami w pracy doradczej jest ilość wykonanych przez doradców usług. Instytucją państwową świadczaca usługi doradcze dla rolników na obszarze wschodniego Mazowsza jest Mazowiecki Ośrodek Doradztwa Rolniczego (MODR) z siedzibą w Warszawie Oddział Siedlce. Analiza wykonanych usług doradczych dotyczyła terenu sześciu powiatów: siedleckiego, węgrowskiego, garwolińskiego, łosickiego, sokołowskiego i mińskiego. Do analizy wykorzystano dane trzyletniej pracy doradców. Szczególną uwagę zwrócono na rozmieszczenie i dostępność usług dla rolników. Opracowanie powstało na podstawie przeglądu dostępnych dokumentów wewnętrznych MODR oraz literatury przedmiotu.

\section{Wyniki badań}

W ostatnich latach w Polsce podejmowano działania, mające na celu uporządkowanie struktur organizacyjnych doradztwa rolniczego. Obecnie funkcjonowanie doradztwa państwowego reguluje Ustawa o jednostkach doradztwa rolniczego przyjęta przez Sejm 22.10.2004 roku. Zapisy tej Ustawy weszły w życie 01.01.2005 r., reformowały one doradztwo rolnicze i ograniczały częściowo występowanie sporów kompetencyjnych oraz powielanie się zadań jednostek doradztwa rolniczego (Ustawa o jednostkach doradztwa rolniczego z dn. 22 października $2004 \mathrm{r}$. (Dz.U. z 2013 poz. 474 z późn. zm.).

W Mazowieckim Ośrodku Doradztwa Rolniczego wyodrębnia się trzy poziomy organizacyjne: wojewódzki, oddziałowy i terenowy. Za całokształt funkcjonowania MODR Warszawa odpowiada dyrektor, który kieruje Wojewódzkim Ośrodkiem przy pomocy dwóch zastępców, głównego księgowego, dyrektorów Oddziałów oraz kierowników komórek organizacyjnych. Drugi poziom stanowią Oddziały (Regulamin organizacyjny Mazowieckiego Ośrodka Doradztwa Rolniczego w Warszawie). Siedlecki Oddział jest jednym z sześciu oddziałów MODR obejmując swoim działaniem wschodnią część województwa mazowieckiego, teren sześciu powiatów: siedleckiego, węgrowskiego, garwolińskiego, łosickiego, sokołowskiego i mińskiego, gdzie zlokalizowanych jest 59 gmin. Ogółem na terenie działania Oddziału Siedlce znajduje się 1498 wsi i ponad 68 tysięcy gospodarstw rolnych.

Pracownicy Oddziału Siedlce w latach 2012-2014 kontynuowali realizację założeń Krajowego Progra$\mathrm{mu}$ Rozwoju Wsi, skoordynowanego ze Strategią Rozwoju Kraju na lata 2007-2013. Obecność Polski w Unii Europejskiej i dokonujące się od kilku lat procesy dostosowawcze $\mathrm{w}$ rolnictwie ukierunkowały doradztwo rolnicze na działania związane z problematyką dotyczącą procesu dostosowania warunków produkcji rolnej do standardów Unii Europejskiej. Działania na rzecz tego rozwoju dotyczyły: organizacji szkoleń, pokazów, wdrażania demonstracji i programów doradczych dla rolników. Ich celem był 
the EU standards. The measures undertaken for this development included: the organisation of training courses, presentations, demonstrations and the implementation of advisory programs for farmers. Their aim was the raise the efficiency and quality of the product. While performing these tasks, advisers carried out work related to the issues of: rural area development, economics, agricultural accounting, marketing, entrepreneurship, implementation of the EU's agricultural policy, ecology, environmental protection, multi-directional development of rural households and technology for plant, horticultural and animal production.

Since October 2010 the Siedlce Branch of MAAC has operated on the basis of a new structure composed of panels dedicated to particular issue groups and six Local Advisory Teams in Łosice, Mińsk Mazowiecki, Sokołów Podlaski, Siedlce, Garwolin and Węgrów, which represent the third level in the organisational structure of MAAC.

In 2014, the Siedlce Branch Office of MAAC Warsaw employed 102 personnel, of which 96 were active while the rest were on long unpaid leaves. In the Teams of the Branch Office a total of 32 people were employed, 10 of whom were employees of the Accounting Department, Applied Information Technology, Administration and Economic departments. The remaining 22 people were employed in the so-called advisory teams, which are essentially responsible for services supplied to farmers. The Local Advisory Teams employed 64 advisers, responsible for the direct contact with the farmer in a given commune. Therefore, the personnel of agricultural advisers was composed of 86 employees. Compared to 2012 the total employment increased by 3 employees, with the simultaneous reduction of the number of advisers by 4. Taking into consideration the number of people on long unpaid leaves, of which there were 4 in 2012 , we can conclude that in the structure of employment during the analysed period, no significant changes occurred.

The changes in advisory systems and the growing need to connect consulting with the entire system of agricultural knowledge stems from contemporary conditions and changes in agriculture and rural areas. The key changes include globalisation, trade liberalisation and the growing competition resulting from those factors, decreasing the number of farmers, the adoption of new non-productive functions by rural areas and farmers, as well as universal, sustainable development, with considerations for environmental protection and rational management of resources (Firle, Rydz 2012). The process of information flow in such an extensive organisational structure is quite complicated. The provision of the most up-to-date and highest quality of service requires specialists in various fields to obtain more information, which takes place during various training sessions, conferences and seminars, as well as through the analysis of legislation, regulations and various implementing acts. Accumulating data is the responsibility of the people working in the Departments and Teams at the headquarters. Then they transfer it to the wzrost efektywności oraz jakości produktu. Wykonując wymienione zadania doradcy realizowali zagadnienia z zakresu: rozwoju obszarów wiejskich, ekonomiki, rachunkowości rolnej, marketingu, przedsiębiorczości, wdrażania polityki rolnej Unii Europejskiej, ekologii, ochrony środowiska, wielokierunkowego rozwoju wiejskich gospodarstw domowych oraz technologii produkcji: roślinnej, ogrodniczej i zwierzęcej.

MODR Oddział Siedlce od października 2010 roku funkcjonuje w oparciu o nową strukturę złożoną z zespołów merytorycznych oraz sześciu Terenowych Zespołów Doradczych w Łosicach, Mińsku Mazowieckim, Sokołowie Podlaskim, Siedlcach, Garwolinie i Węgrowie, które stanowią trzeci poziom w strukturze organizacyjnej MODR.

W 2014 roku w MODR Warszawa Oddział Siedlce zatrudnionych było 102 pracowników, w tym aktywnych było 96, zaś pozostali przebywali na długich urlopach bezpłatnych. W Zespołach Oddziału pracowało ogółem 32 osoby, z których 10 to pracownicy Zespołów Księgowości, Zastosowań Teleinformatyki i Administracyjno-Gospodarczego, pozostałe 22 osoby były zatrudnione w tzw. zespołach doradczych, które merytorycznie odpowiadaja za obsługę rolników. W Terenowych Zespołach Doradczych pracowało 64 doradców, którzy odpowiadali za bezpośredni kontakt z rolnikiem w gminie. Kadrę doradców rolniczych stanowiło zatem 86 pracowników. W porównaniu do 2012 roku ogólne zatrudnienie zwiększyło się o 3 pracowników, przy jednoczesnym zmniejszeniu liczby doradców o 4. Biorąc pod uwagę liczbę osób na długich urlopach bezpłatnych, których w 2012 było 4, można stwierdzić, że w strukturze zatrudnienia w analizowanym czasie nie zachodziły znaczące zmiany.

Zmiany w systemach doradztwa oraz rosnaca potrzeba powiązania doradztwa $\mathrm{z}$ całym systemem wiedzy rolniczej wynika ze współczesnych uwarunkowań oraz przemian $\mathrm{w}$ rolnictwie i na obszarach wiejskich. Podstawowe zmiany to globalizacja, liberalizacja handlu i wynikająca z tego coraz silniejsza konkurencja, zmniejszanie się liczby rolników, podejmowanie przez wieś i rolników nowych funkcji pozaprodukcyjnych oraz powszechny zrównoważony rozwój, uwzględniający ochronę środowiska i racjonalną gospodarkę zasobami (Firlej, Rydz 2012). Proces przepływu informacji w tak rozległej strukturze organizacyjnej jest dość skomplikowany. Zapewnienie najbardziej aktualnej i najwyższej jakości świadczonych usług wymaga pozyskiwania informacji przez specjalistów z poszczególnych dziedzin, które odbywa się na różnego rodzaju szkoleniach, konferencjach i seminariach, jak również poprzez analizę dokumentów ustaw, rozporządzeń i różnych aktów wykonawczych. Pozyskiwaniem informacji zajmują się osoby zatrudnione w Działach w centrali oraz Zespołach w Oddziale, a następnie przekazują je na niższe szczeble organizacji. Proces ten odbywa się na wiele sposobów, jednak najczęściej jest to forma narad lub szkoleń, w których biorą udział kierownicy lub specjaliści z podległych komórek. Część użytecznej wiedzy każdy doradca może pozyskiwać sam 
lower levels of the organisation. This process takes place in many ways, but the most common one is the form of conferences or training sessions, with the participation of managers or specialists from subordinate departments. Each consultant can obtain part of the useful knowledge by themselves in the process of self-education and training, in which they directly participate.

Advisers raised their qualifications by participating in various training sessions and e-learning courses organised by, among others: the Agricultural Advisory Centre, Ministry of Agriculture and Rural Development, universities, research institutes, MAAC and other units with competences for conducting educational activities. During the analysed period advisers participated in 341 training courses, which they attended 2,146 times. w procesie samokształcenia oraz szkoleń, w których bierze bezpośrednio udział.

Doradcy podnosili swoje kwalifikacje zawodowe uczestnicząc w różnego rodzaju szkoleniach oraz kursach e-learningowych organizowanych między innymi przez: Centrum Doradztwa Rolniczego, Ministerstwo Rolnictwa i Rozwoju Wsi, uczelnie, instytuty naukowe, MODR i inne jednostki z uprawnieniami prowadzenia działalności oświatowej. $\mathrm{W}$ badanym okresie doradcy uczestniczyli w 341 szkoleniach, w których wzięli udział 2146 razy.

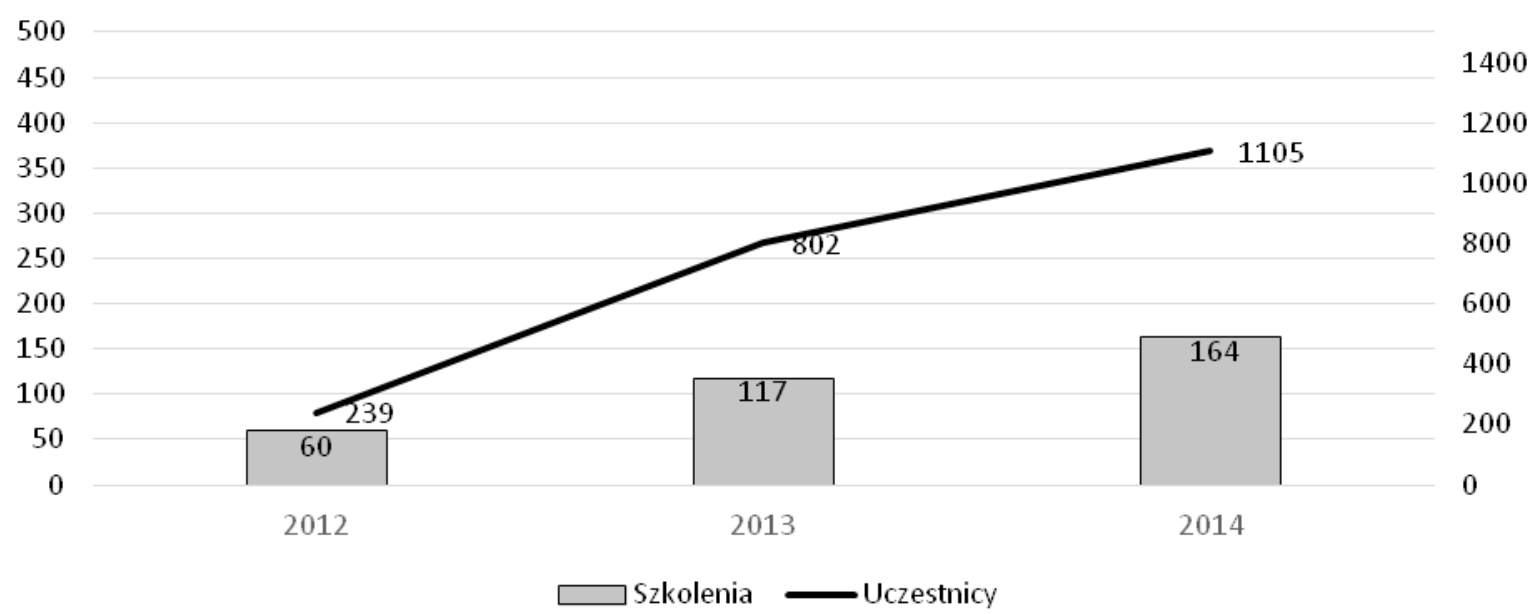

Legend: Szkolenia - Training sessions/courses; Uczestnicy - Participants

Figure 1. The number of training courses attended by advisers with the number of people participating, carried out at MAAC Branch Office in Siedlce during the years 2012 - 2014

Rysunek 1. Liczba szkoleń w których wzięli udział doradcy i liczba osób w nich uczestniczących realizowanych w MODR Oddział Siedlce w latach $2012-2014$

Source: the authors' own elaboration based on reports of the Siedlce Branch of MAAC for the period 2012-2014.

Źródło: opracowanie własne na podstawie sprawozdań z działalności MODR Oddział Siedlce za lata 2012-2014.

The data indicate (Figure 1), that the number of training sessions with the participation of advisory staff increases every year. On average, within three years, one adviser took part in approx. six different courses. Priority subjects of the training courses or sessions were: agricultural-environmental programmes, rules on filling in applications for direct payments, cross-compliance requirements, animal welfare, agricultural entrepreneurship, types of taxation, African swine fever, integrated pest management and other issues related to the issues of technology, environmental protection and ecology.

The purpose of educational and informative activities is continual complementation and improvement of the qualifications of advisers. Through training courses or sessions, they acquire the necessary knowledge needed to perform the educational, advisory, informative and promotional tasks as well as those consisting in direct assistance
Dane wskazują (rysunek 1.), że ilość szkoleń w których bierze udział kadra doradcza z roku na rok się zwiększa. Średnio w ciągu trzech lat, jeden doradca uczestniczył w ok. sześciu różnych szkoleniach. Priorytetowymi tematami szkoleń były: programy rolnośrodowiskowe, zasady wypełniania wniosków o płatności bezpośrednie, wymogi wzajemnej zgodności, dobrostan zwierząt, przedsiębiorczość rolnicza, rodzaje opodatkowania, afrykański pomór świń, integrowana ochrona roślin oraz inne dotyczące problematyki technologicznej, ochrony środowiska i ekologii.

Celem działalności oświatowej i informacyjnej jest ustawiczne uzupełnianie i podnoszenie kwalifikacji doradców. Poprzez szkolenia nabywają niezbędną wiedzę, potrzebną im do realizacji zadań edukacyjnych, doradczych, informacyjnych, upowszechnieniowych jak również polegających na udzielaniu rolnikom bezpośredniej pomocy $\mathrm{w}$ pozyskiwaniu 
for farmers in obtaining funds to support agriculture and rural areas.

The knowledge acquired by the advisers enables them to provide services to farmers at an appropriate level. During the years 2012 - 2014 the consultants of the Siedlce Branch cooperated, among others, with: organic farms, farms in the scope of agricultural accounting (FADN), in the scope of rural households and agritourism, environmental management scheme farms and agricultural producer groups (Figure 2). In 2012 , there were 30 producer groups which gathered 852 members. In the subsequent years, 20 groups were involved in the cooperation, with the number of about 600 affiliated farmers. środków na wsparcie rolnictwa i obszarów wiejskich.

Nabyta wiedza pozwala doradcom na świadczenie usług rolnikom na odpowiednim poziomie. Doradcy Oddziału Siedlce w latach 2012 - 2014 współpracowali między innymi z: gospodarstwami ekologicznymi, gospodarstwami w zakresie prowadzenia rachunkowości rolnej (FADN), z gospodarstwami w zakresie gospodarstwa wiejskiego i agroturystyki, gospodarstwami rolnośrodowiskowymi oraz grupami producentów rolnych (rysunek 2.). Grupy producentów w 2012 roku liczyły 30 i skupiały 852 członków. A w kolejnych latach współpraca dotyczyła 20 grup, z liczbą około 600 zrzeszonych rolników.

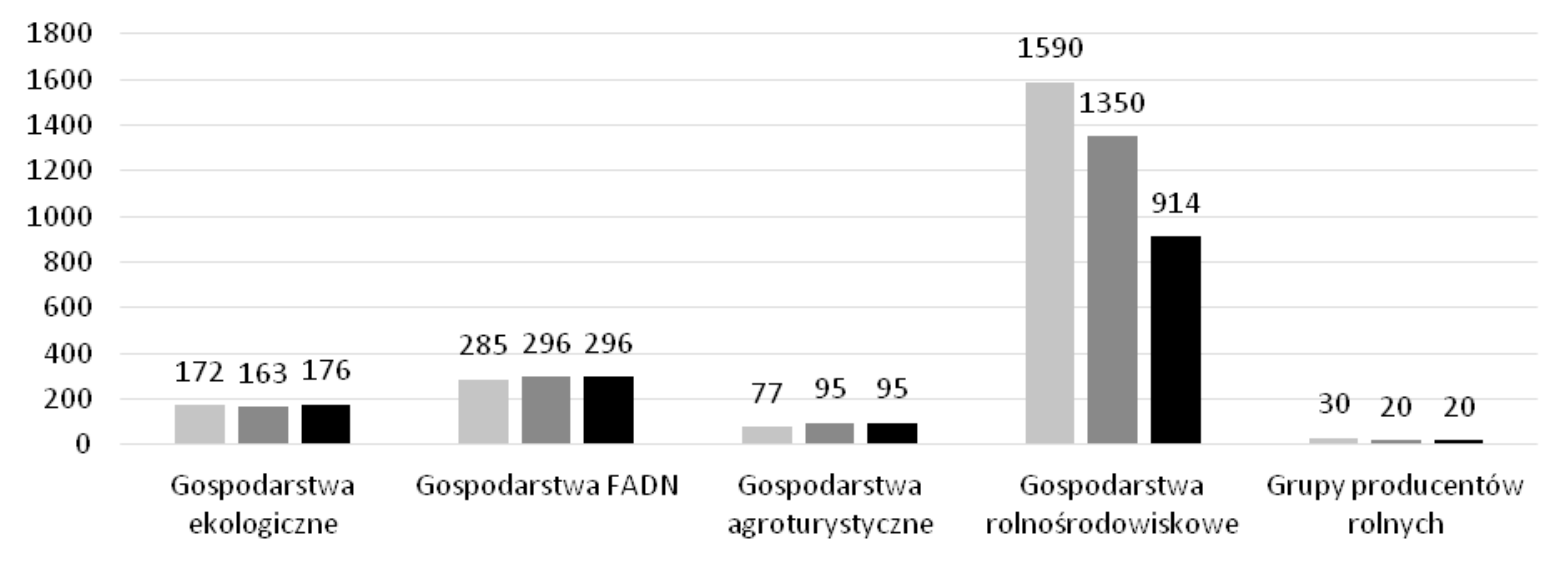

$2012 \square 2013 \square 2014$

Legend: Gospodarstwa ekologiczne - Ecological farms; Gospodarstwa FADN - Farms implementing FADN; Gospodarstwa agroturystyczne - Agritourism farms Gospodarstwa rolnośrodowiskowe - Farms with environmental management schemes; Grupy producentów rolnych - Agricultural producer groups

Figure 2. The number of farms and groups cooperating with A Branch in Siedlce in the years 2012 - 2014 Rysunek 2. Liczba gospodarstw oraz grup współpracujących z MODR Oddział Siedlce w latach 2012 - 2014 Source: the authors' own elaboration based on reports of the activities of the Siedlce Branch of MAAC during the years 20122014.

Źródło: opracowanie własne na podstawie sprawozdań z działalności MODR Oddział Siedlce za lata 2012-2014.

From the point of view of activities conducted by MAAC and the services provided by it, the employees of Local Advisory Teams, who establish direct contact with farmers in the community, have the most important task. The personnel of the branch and provincial levels play a supportive role, coordinate their activities and organize major forms of training, e.g. conferences and large-scale training sessions for entire branches.

The work of Local Advisory Teams is guided by managers who answer directly to the Branch Director. The staff is composed of agricultural advisers, each of whom is assigned to a different community and advisers for handling tasks of the Rural Economy Team - Entrepreneurship, Rural Household and Agritourism.

During the analysed period of time the consultants of the Siedlce Branch carried out tasks in the field of agricultural advisory services as part of educational, promotional, advisory and informative
Z punktu widzenia prowadzonej przez MODR działalności i świadczonych usług najważniejsze zadanie pełnią pracownicy Terenowych Zespołów Doradczych, którzy nawiązują bezpośredni kontakt $\mathrm{z}$ rolnikiem w gminie. Pracownicy szczebla oddziałowego i wojewódzkiego pełnią rolę wspomagającą oraz koordynującą ich działania jak również organizują większe formy szkoleniowe np. konferencje i duże szkolenia oddziałowe.

Pracą Terenowych Zespołów Doradczych, kierują kierownicy, którzy bezpośrednio podlegają Dyrektorowi Oddziału. Obsadę stanowią doradcy rolniczy, gdzie każdy z nich ma przypisaną do siebie gminę, którą obsługuje oraz doradcy do obsługi zadań Zespołu GW - Przedsiębiorczości, Wiejskiego Gospodarstwa Domowego i Agroturystyki.

Doradcy Oddziału Siedlce w analizowanym okresie realizowali zadania $\mathrm{z}$ zakresu doradztwa rolniczego w ramach zadań szkoleniowych, upowszechnieniowych, doradczych i informacyjnych. W latach 
tasks. During the years 2012 - 2014 advisory services under the Rural Development Programme included activities that were related to the call for proposals and implementation of obligations arising from the contracts signed by beneficiaries in the previous years. Completing applications and other documentation related to obtaining financial aid was an important element of advisory services and undoubtedly contributed to the improvement in the level of farmers' income and the improvement the farms' competitiveness.

During a three-year period, assistance in drafting applications and performing advisory services in various areas of consulting, in the total number of 12.723 was supplied at a charge. During the threeyear period 1 adviser had 148 applications to draft on average. Analysing the data in particular years (tab. 1) one can observe a decrease of farmers' interest in the services supplied by advisers at a charge. In 2014 advisers developed 20\% fewer applications and paid services than in 2012. In 2012 one adviser performed, on average, more than 52 services at a charge, while in 2014 no more than 44 . This phenomenon may result from increasing competition, as there are increasingly companies within the Branch Office territory which perform a similar range of activities. The farmers' knowledge on this topic also increases and some of them fill in some of applications themselves, e.g. applications for direct payments.
2012 - 2014 doradztwo w zakresie Programu Rozwoju Obszarów Wiejskich obejmowało działania, które były związane z naborem wniosków oraz realizacja zobowiązań wynikających $\mathrm{z}$ podpisanych umów beneficjentów w poprzednich latach. Wypełnianie wniosków i innej dokumentacji związanej z uzyskaniem pomocy finansowej stanowiło ważny element w pracy doradczej i w niewątpliwy sposób przyczyniło się do poprawy poziomu dochodów rolniczych oraz podnoszenia konkurencyjności gospodarstw rolnych.

W ciągu trzyletniego okresu świadczono odpłatną pomoc w wykonaniu ogółem 12723 wniosków oraz usług z różnych zakresów doradztwa. W ciągu trzyletniego okresu na 1 doradcę przypadało wykonanie średnio 148 wniosków. Analizując dane w poszczególnych latach (tab. 1) można zauważyć, że następował spadek zainteresowania rolników usługami świadczonymi odpłatnie przez doradców. W 2014 r. doradcy wykonali 20\% mniej wniosków i usług płatnych niż w 2012r. W 2012 roku jeden doradca wykonywał średnio ponad 52 usługi płatne, gdy w 2014 już tylko niecałe 44. Zjawisko to może wynikać ze zwiększającej się konkurencji, gdzie na terenie Oddziału powstaje coraz więcej firm świadczących podobny zakres działań. Zwiększa się też wiedza rolników na ten temat i część z nich sama wypełnia niektóre wnioski np. o płatności bezpośrednie.

Table 1. The summary of applications and paid services performed by the advisors at the Siedlce Branch of MAAC during the years 2012 - 2014

Tabela 1. Zestawienie wykonanych przez doradców wniosków i usług odpłatnych w MODR Oddział Siedlce w latach 2012 - 2014

\begin{tabular}{|l|c|c|c|}
\multicolumn{1}{|c|}{\begin{tabular}{c}
\multicolumn{1}{|c|}{$\begin{array}{c}\text { Type of application, services/ } \\
\text { Rodzaj wniosku, usługi }\end{array}$} \\
\cline { 2 - 4 }
\end{tabular}} & $\mathbf{2 0 1 2}$ & $\mathbf{2 0 1 3}$ & $\mathbf{2 0 1 4}$ \\
\hline Direct payments/ Płatności bezpośrednie & 3312 & 3072 & 3027 \\
\hline $\begin{array}{l}\text { Payments with a declaration of environmental management scheme package/ } \\
\text { Płatności z deklaracją pakietów rolnośrodowiskowych }\end{array}$ & 661 & 631 & 552 \\
\hline $\begin{array}{l}\text { Planning environmental management scheme activities/ } \\
\text { Plan działalności rolnośrodowiskowej }\end{array}$ & 597 & 394 & 153 \\
\hline Business plan/ Biznes plan & 118 & 123 & 21 \\
\hline $\begin{array}{l}\text { Use of advisory services by farmers and forest owners/ In total/ Razem: } \\
\text { Korzystanie z usług doradczych przez rolników i posiadaczy lasów }\end{array}$ & 19 & 19 & 24 \\
\hline \multicolumn{1}{|c|}{4707} & 4239 & 3777 \\
\hline
\end{tabular}

Source: the authors' own elaboration based on reports of the activities of the Siedlce Branch of MAAC during the years 20122014.

Źródło: opracowanie własne na podstawie sprawozdań z działalności MODR Oddział Siedlce za lata 2012-2014.

Training was also available at a charge during courses in pesticide application. In total, 188 training courses were carried out during the examined period, during which 5450 farmers. On average during the analysed period, one adviser organised two courses in agrochemical application. Figure 3 shows the list of completed training sessions in the use of pesticides.

The transfer of knowledge to farmers is the most important statutory activity of MAAC. It consisted of two activities, i.e. training and advisory services. The training process is more complicated logistically, because it can take place within the commune, county, in the branch headquarters or outside it, in
Szkolono też odpłatnie na kursach stosowania środków ochrony roślin. Ogółem w badanym okresie przeprowadzono 188 szkoleń, na których 5450 rolników zdobyło uprawnienia. Średnio w ciągu badanego okresu na 1 doradcę przypadała organizacja 2 kursów chemizacyjnych. Rysunek 3 przedstawia zestawienie wykonanych szkoleń z zakresu stosowania środków ochrony roślin.

Najważniejszą działalnością statutową MODR jest przekazywanie wiedzy rolnikom. Składały się na nią dwa działania tj. szkolenia i porady. Logistycznie proces szkoleń jest bardziej skomplikowany, gdyż może odbywać się na terenie gminy, w powiecie, w sie- 


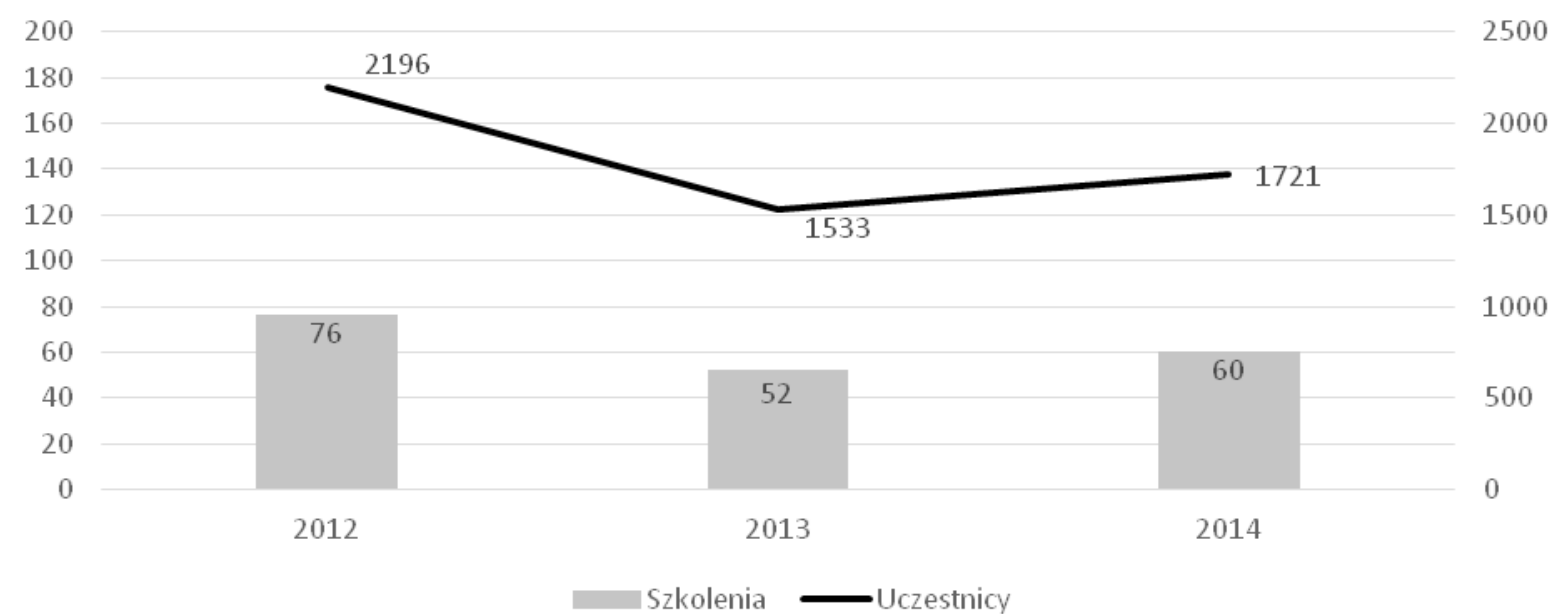

Legend: Szkolenia - Training sessions/courses; Uczestnicy - Participants

Figure 3. The summary of training sessions "The application of pesticide products using ground equipment intended for the use of these agents, with the exception of equipment mounted on rail vehicles and other equipment used in railway "carried out by the Siedlce Branch of MAAC during the years 2012 - 2014

Rysunek 3. Zestawienie szkoleń „Stosowanie środków ochrony roślin przy użyciu sprzętu naziemnego przeznaczonego do stosowania tych środków, z wyłączeniem sprzętu montowanego na pojazdach szynowych oraz innego sprzętu stosowanego w kolejnictwie" zrealizowanych przez MODR Oddział Siedlce w latach 2012 - 2014

Source: the authors' own elaboration based on reports of the activities of the Siedlce Branch of MAAC during the years 20122014.

Źródło: opracowanie własne na podstawie sprawozdań z działalności MODR Oddział Siedlce za lata 2012-2014.

the form of the so-called field training. Field workers are responsible for the organisation of training in communes or counties. The trainers were field consultants, or specialists from the branch office invited by them. In the periods of the largest number of conducted training sessions, e.g. in the first quarter of the year, when lecturers in the field were specialists from the branch office, it was important to inform the persons interested in participation of the training timetable in advance. The transport of specialist to field training sessions was dependent on the availability of three company cars, whose number did not change over three years. Public transport or travelling in a private car as part of the secondment was also possible, but due to the high costs of using private cars they were rarely used for this purpose. So-called activity days were assigned to the counties, during which they were obliged to organise training sessions with the participation of in-company specialists. These logistical solutions caused travel costs to be minimised, since instead of several trips a day to various counties, only one car was needed for transportation to one county carrying several specialists who trained several communes. Such practices allowed for streamlining educational activities and substantial savings.

According to the data presented in Figure 4, each year in the Siedlce Branch operating area several hundred stationary training sessions were organised, thus enabling the residents of rural areas to improve their agricultural knowledge. On average 12 training sessions were held per one adviser. dzibie oddziału lub poza oddziałem tzw. szkolenia wyjazdowe. Za organizację szkoleń w gminach lub w powiatach odpowiadają pracownicy terenowi. Osobami szkolącymi byli doradcy terenowi lub zapraszani przez nich specjaliści z oddziału. W okresach realizacji największej liczby szkoleń np. w pierwszym kwartale roku, gdy wykładowcami w terenie mieli być specjaliści z oddziału, ważne było odpowiednio wczesne poinformowanie zainteresowanych osób o terminach szkoleń. Dojazd specjalistów na szkolenia $\mathrm{w}$ terenie uzależniony był od dostępności samochodów służbowych, która na przełomie trzech lat się nie zmieniała i wynosiła tylko trzy. Możliwy był również dojazd $w$ ramach delegacji służbowych środkami komunikacji publicznej lub samochodami prywatnymi, jednak ze względu na duże koszty użycia samochodów prywatnych były one rzadko używane do takich celów. Powiaty miały wyznaczone tzw. swoje dni, kiedy powinny organizować szkolenia z udziałem specjalistów zakładowych. Takie logistyczne rozwiązanie powodowało, że minimalizowane były koszty dojazdu, zamiast kilku wyjazdów jednego dnia do różnych powiatów, mógł wyjechać tylko jeden samochód do jednego powiatu, ale z kilkoma specjalistami, którzy szkolili w kilku gminach. Takie praktyki dawały możliwość uporządkowania działań szkoleniowych i wymierne oszczędności.

Jak wynika z danych przedstawionych na rysunku 4, na terenie działalności Oddziału Siedlce każdego roku organizowano kilkaset szkoleń stacjonarnych, umożliwiając $\mathrm{w}$ ten sposób mieszkańcom obszarów wiejskich udoskonalanie ich wiedzy rolniczej. Na 1 doradcę przypadała organizacja średnio 12 szkoleń. 


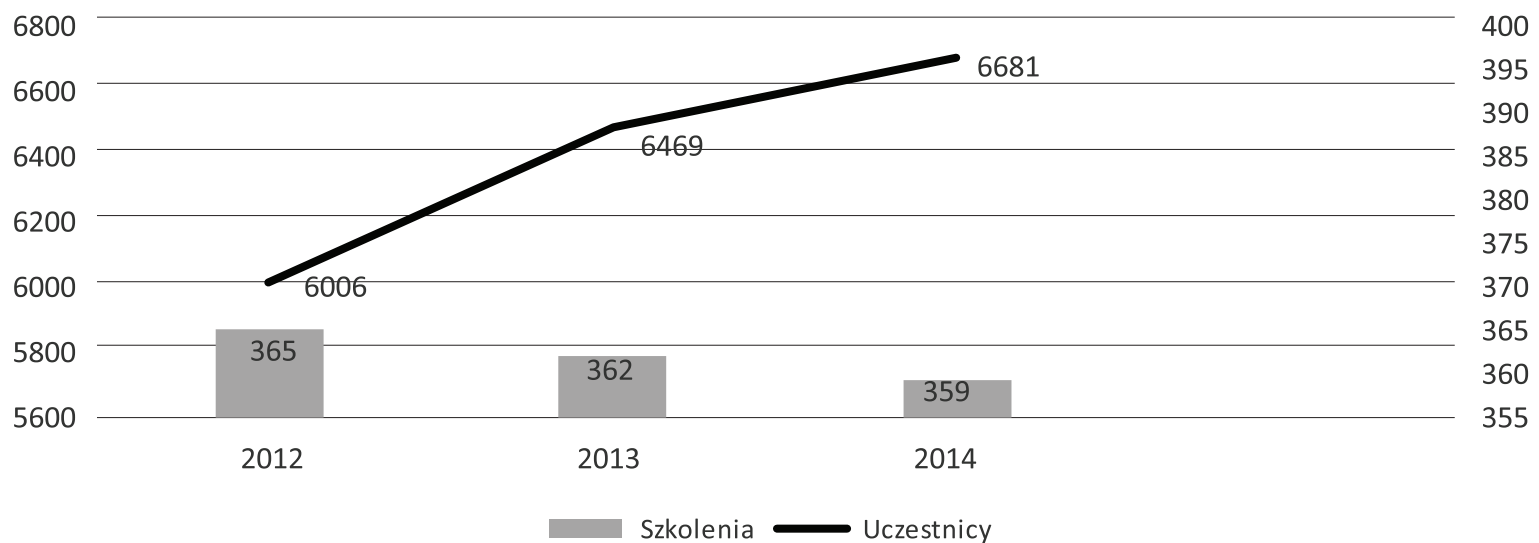

Legend: Szkolenia - Training sessions/courses; Uczestnicy - Participants

Figure 4. The number of stationary training sessions carried out by the Siedlce Branch Office of MAAC and their participants over the period $2012-2014$

Rysunek 4. Liczba szkoleń stacjonarnych i osób w nich uczestniczących realizowanych przez MODR Oddział Siedlce w latach 2012-2014

Source: the authors' own elaboration based on reports of the activities of the Siedlce Branch of MAAC during the years $2012-2014$. Źródło: opracowanie własne na podstawie sprawozdań z działalności MODR Oddział Siedlce za lata 2012-2014.

Table 2. Educational activities of the advisers from the MAAC Branch in Siedlce over the period of 2012 - 2014

Tabela 2. Działania szkoleniowe doradców w MODR Oddział Siedlce w latach 2012 - 2014

\begin{tabular}{|c|c|c|c|c|}
\hline \multirow[b]{3}{*}{$\begin{array}{l}\text { No./ } \\
\text { Lp. }\end{array}$} & \multirow[b]{3}{*}{ Activity/Działanie } & \multicolumn{3}{|c|}{ Year/ Rok } \\
\hline & & 2012 & 2013 & 2014 \\
\hline & & \multicolumn{3}{|c|}{$\begin{array}{l}\text { The number of sta- } \\
\text { tionary training } \\
\text { sessions/courses/ } \\
\text { Liczba szkoleń sta- } \\
\text { cjonarnych }\end{array}$} \\
\hline 1 & $\begin{array}{l}\text { Assistance in applying for aid financed or co-financed with the European Union funds or other } \\
\text { institutions either domestic or foreign./ } \\
\text { Pomoc w ubieganiu się o przyznanie pomocy finansowanej lub współfinansowanej ze środków } \\
\text { pochodzących z funduszy Unii Europejskiej lub innych instytucji krajowych lub zagranicznych }\end{array}$ & 110 & 79 & 104 \\
\hline 2 & $\begin{array}{l}\text { Promotion of a regional, traditional and local product, as well as cultivation of cultural or natu- } \\
\text { ral heritage of villages and functional furnishing of farm./ } \\
\text { Promocja produktu regionalnego, tradycyjnego i lokalnego oraz kultywowanie dziedzictwa } \\
\text { kulturowego i przyrodniczego wsi oraz funkcjonalnego urządzania gospodarstwa rolnego }\end{array}$ & 28 & 21 & 5 \\
\hline 3 & $\begin{array}{l}\text { Measures aimed at propagating the development of agritourism, as well as tourism in rural are- } \\
\text { as and the promotion of the countryside as an attractive recreational venue./ } \\
\text { Działania na rzecz upowszechniania rozwoju agroturystyki i turystyki na obszarach wiejskich } \\
\text { oraz promocji wsi jako atrakcyjnego miejsca wypoczynku }\end{array}$ & 4 & 15 & 33 \\
\hline 4 & $\begin{array}{l}\text { The management of an agricultural farm/ } \\
\text { Zarządzanie gospodarstwem rolnym }\end{array}$ & 6 & 43 & 21 \\
\hline 5 & $\begin{array}{l}\text { Accounting in agricultural farms (FADN)/ } \\
\text { Rachunkowość w gospodarstwach rolnych (FADN) }\end{array}$ & 7 & 6 & 6 \\
\hline 6 & $\begin{array}{l}\text { The development of entrepreneurship in rural areas/ } \\
\text { Rozwój przedsiębiorczości na obszarach wiejskich }\end{array}$ & 8 & 7 & 5 \\
\hline 7 & $\begin{array}{l}\text { Popularisation of the latest technological solutions/ } \\
\text { Popularyzacja najnowszych rozwiązań technologicznych }\end{array}$ & 84 & 96 & 99 \\
\hline 8 & $\begin{array}{l}\text { Popularisation of the cross-compliance principle and occupational safety and health on farms/ } \\
\text { Popularyzacja zasady wzajemnej zgodności cross-compliance oraz BHP w gospodarstwie rolnym }\end{array}$ & 44 & 32 & 33 \\
\hline 9 & \begin{tabular}{|l|} 
Measures for ecological agriculture development/ \\
Działania na rzecz rozwoju rolnictwa ekologicznego
\end{tabular} & 15 & 10 & 12 \\
\hline 10 & $\begin{array}{l}\text { Supporting the implementation of the Agricultural and Environmental Programmes/ } \\
\text { Wspieranie wdrażania Programów Rolnośrodowiskowych }\end{array}$ & 44 & 37 & 35 \\
\hline 11 & $\begin{array}{l}\text { Environmental protection in agriculture, including the reduction of pollution with agricultural origin/ } \\
\text { Ochrona środowiska w rolnictwie w tym ograniczenie zanieczyszczeń pochodzenia rolniczego }\end{array}$ & 15 & 16 & 6 \\
\hline
\end{tabular}

Source: the authors' own elaboration based on reports of the activities of the Siedlce Branch of MAAC during the years 2012-2014. Źródło: opracowanie własne na podstawie sprawozdań z działalności MODR Oddział Siedlce za lata 2012-2014. 
The data presented in Table 2. present the issues of the training sessions and their number. Training forms were adjusted to the emerging educational needs. This was particularly visible in the case of training courses on the Rural Development Programme, access to EU funds, ecology (in this case mainly training in environmental management scheme schemes and ecological farming). Training courses in agricultural production technology and agritourism aroused great interest.

The form of training, which gathered the most participants was a conference (Figure 5). In recent years, there has been an increase in the number of conferences held and great interest in this form of training. In 2012 one conference was attended by 40 farmers. A year later, on average, one conference gathered 91 farmers and in 2014 over 128 people. In this area, we could see increasing interest in this form of training.
Dane przedstawione $\mathrm{w}$ tabeli 2 . przedstawiają problematykę realizowanych szkoleń i ich liczbę. Szkolenia były dostosowywane do pojawiających się potrzeb oświatowych. Szczególnie było to widoczne w przypadku szkoleń dotyczących Programu Rozwoju Obszarów Wiejskich, pozyskiwania funduszy ze środków unijnych, ekologii (w tym przypadku były to głównie szkolenia z zakresu programów rolnośrodowiskowych i rolnictwa ekologicznego). Dużym zainteresowaniem cieszyły się szkolenia z technologii produkcji rolniczej oraz agroturystyki.

Formą szkoleniową, która gromadziła najwięcej uczestników była konferencja (rysunek 5). W ostatnich latach nastąpił wzrost ilości zrealizowanych konferencji oraz duże zainteresowanie rolników tego typu formą szkoleniową. W 2012 r. na jednej konferencji było 40 rolników. Rok później na jedną konferencję przypadało 91 rolników, a w 2014 roku już ponad 128 osób. W tym zakresie mogliśmy zaobserwować znaczny progres zainteresowania tą formą szkoleniową.

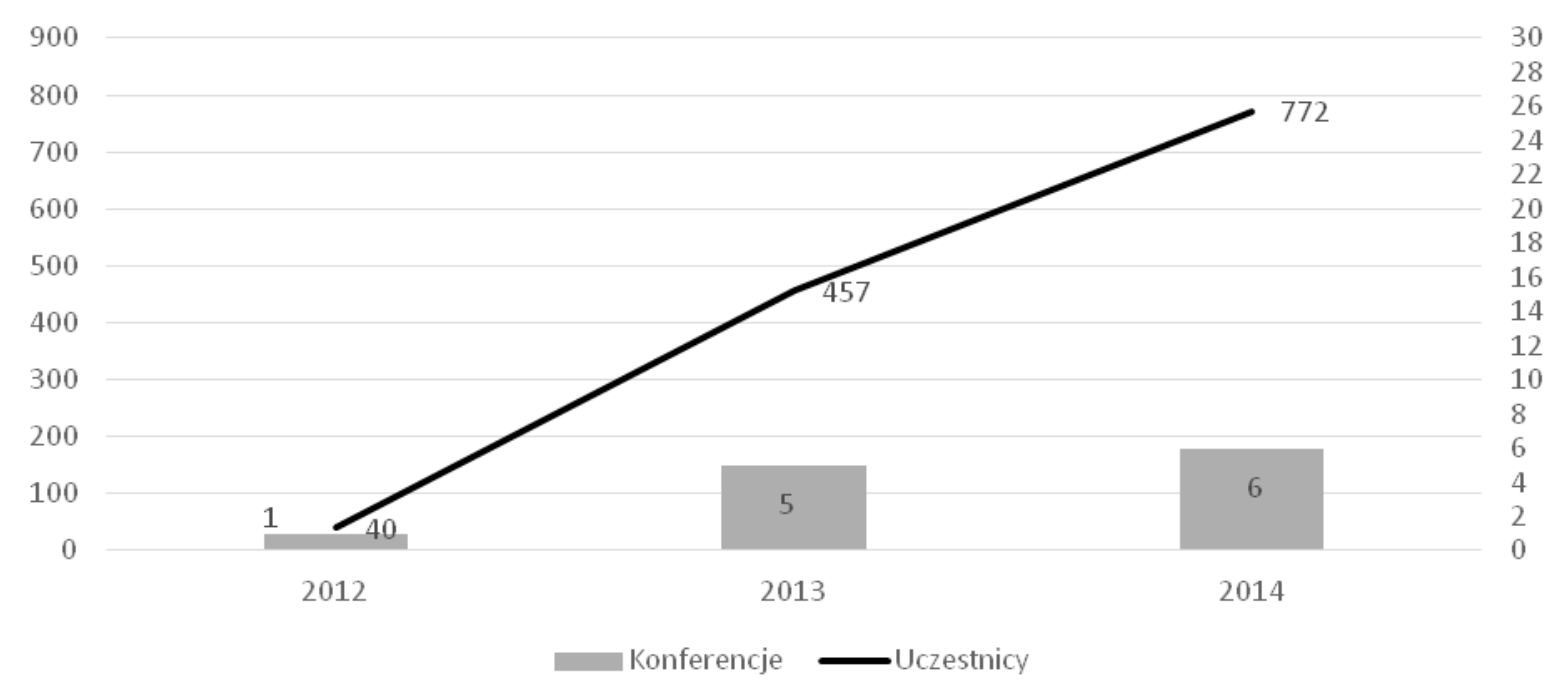

Legend: Konferencje - Conferences; Uczestnicy - Participants

Figure 5. The number of conferences held by the Siedlce Branch of MAAC and their participants over the period of $2012-2014$ Rysunek 5. Liczba konferencji i osób w nich uczestniczących zrealizowanych przez MODR Oddział Siedlce w latach 2012 -2014 Source: the authors' own elaboration based on reports of the activities of the Siedlce Branch of MAAC during the years $2012-2014$. Źródło: opracowanie własne na podstawie sprawozdań z działalności MODR Oddział Siedlce za lata 2012-2014.

Field training sessions were a fairly frequently used form of education in agricultural advisory services. Their purpose was to familiarize the participants with new results of experiments, with innovative experience of other farms in introducing new technologies and innovative forms of organising production. This method has enjoyed constant interest. Every year more than a thousand people had an opportunity to attend fairs, agricultural shows, visits at farms introducing new technical, technological or organisational solutions, which is evidenced by the summary figures related to the number of field training sessions and their participants (Figure 6).
W poradnictwie rolniczym dość często wykorzystywaną metodą były szkolenia wyjazdowe. Celem ich było zapoznanie uczestników z nowymi wynikami doświadczeń, z nowatorskimi doświadczeniami innych gospodarstw wprowadzających nowe technologie i nowoczesne formy organizacji produkcji. Ta metoda cieszyła się niesłabnącym zainteresowaniem. Każdego roku ponad tysiąc osób miało możliwość wyjazdu na targi, wystawy rolnicze, lustracje do gospodarstw wprowadzających nowe rozwiązania techniczne, technologiczne czy organizacyjne, co potwierdzają zestawienia liczby szkoleń wyjazdowych i ich uczestników (rysunek 6). 


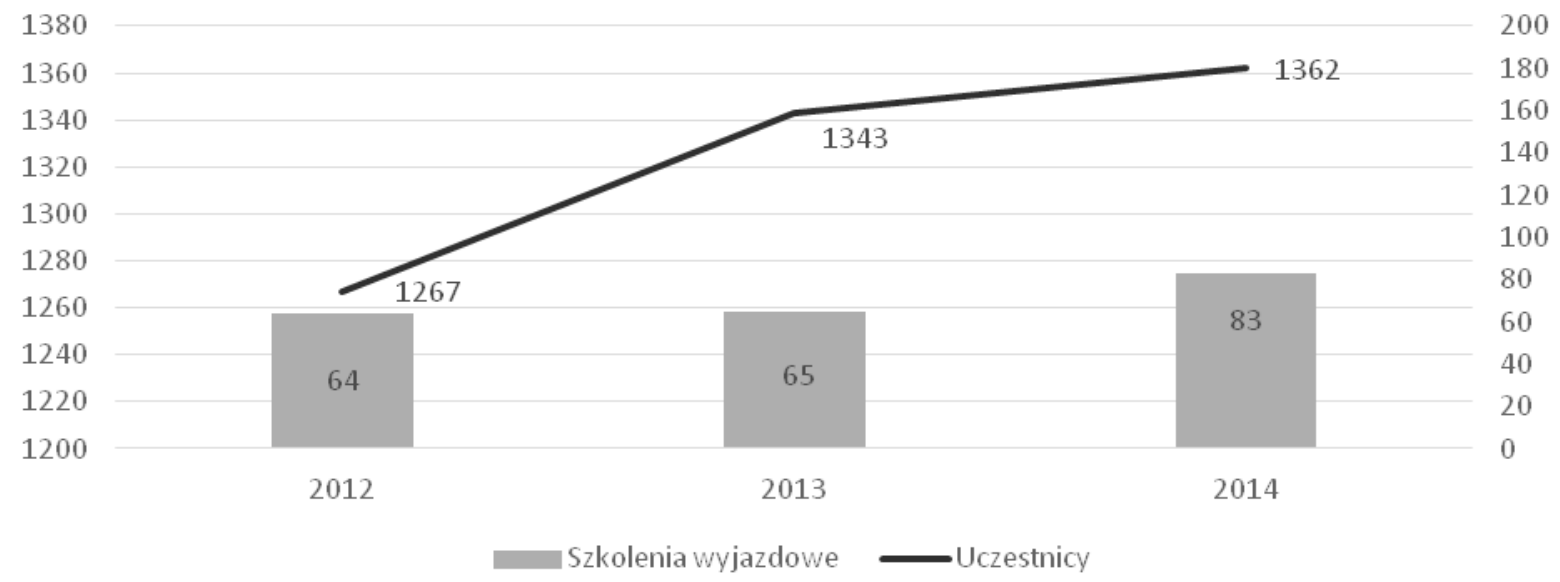

Legend: Szkolenia wyjazdowe - Field training courses/sessions; Uczestnicy - Participants

Figure 6. The number of field training courses/sessions carried out by the Siedlce Branch of MAAC and their participants over the period of $2012-2014$

Rysunek 6. Liczba szkoleń wyjazdowych i osób w nich uczestniczących zrealizowanych przez MODR Oddział Siedlce w latach $2012-2014$

Source: the authors' own elaboration based on reports of the activities of the Siedlce Branch of MAAC during the years $2012-2014$. Źródło: opracowanie własne na podstawie sprawozdań z działalności MODR Oddział Siedlce za lata 2012-2014.

The most common practical method in advisory services were demonstrations. A demonstration is a method of providing advisory services, used mainly to shape farmers' capabilities in plant production, animal production or in handicrafts. In the Siedlce Branch Office the number of demonstrations was maintained at a similar level and oscillated around a hundred and twenty. During the studied period in the Siedlce Branch, 1 field adviser was on average tasked with organising 4 demonstrations.
Najczęściej stosowaną metodą praktyczną w doradztwie były pokazy. Pokaz to metoda doradcza wykorzystywana głównie w celu kształtowania umiejętności rolników czy to w produkcji roślinnej, zwierzęcej czy w rękodzielnictwie. W Oddziale Siedlce liczba pokazów utrzymywała się na podobnym poziomie i oscylowała w granicach stu dwudziestu. W badanym okresie w Oddziale Siedlce na 1 doradcę terenowego przypadła organizacja 4 pokazów.

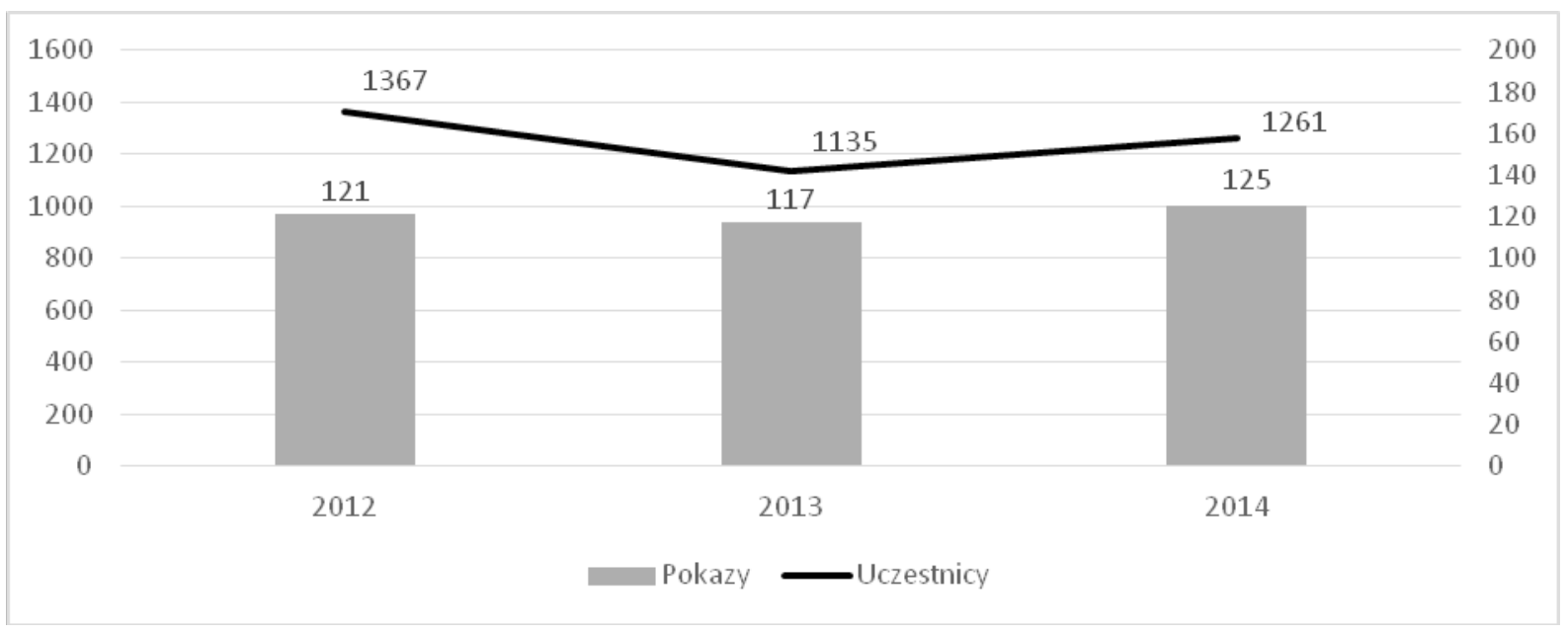

Legend: Pokazy - Demonstrations; Uczestnicy - Participants

Figure 7. The number of demonstrations held by the Siedlce Branch of MAAC and their participants over the period of 2012 $-2014$

Rysunek 7. Liczba pokazów i liczba osób w nich uczestniczących zrealizowanych przez MODR Oddział Siedlce w latach 2012 $-2014$

Source: the authors' own elaboration based on reports of the activities of the Siedlce Branch of MAAC during the years $2012-2014$. Źródło: opracowanie własne na podstawie sprawozdań z działalności MODR Oddział Siedlce za lata 2012-2014. 
The advisers of the Siedlce Branch very often were the organizers or co-organizers of various kinds of contests and competitions that allowed for activation of farmers and popularisation of progress in agriculture. From the data presented in Figure 8 it follows that the advisers working for the Siedlce Branch during the studied period, organised several contests and dozens of competitions related to agricultural and horticultural productions or generally to the functioning of rural areas. During the studied period, on average, 1 adviser was tasked with organising one competition.
Doradcy Oddziału Siedlce bardzo często byli organizatorami bądź współorganizatorami różnego rodzaju konkursów i olimpiad, które umożliwiały aktywizację rolników oraz popularyzowanie postępu $\mathrm{w}$ rolnictwie. $\mathrm{Z}$ danych zaprezentowanych na rysunku 8 wynika że, doradcy pracujący na terenie oddziału siedleckiego w analizowanym okresie organizowali kilkanaście konkursów i kilkadziesiąt olimpiad związanych z produkcją rolniczą, sadowniczą czy ogólnie funkcjonowaniem obszarów wiejskich. W badanym okresie średnio na 1 doradcę przypadała organizacja 1 olimpiady.

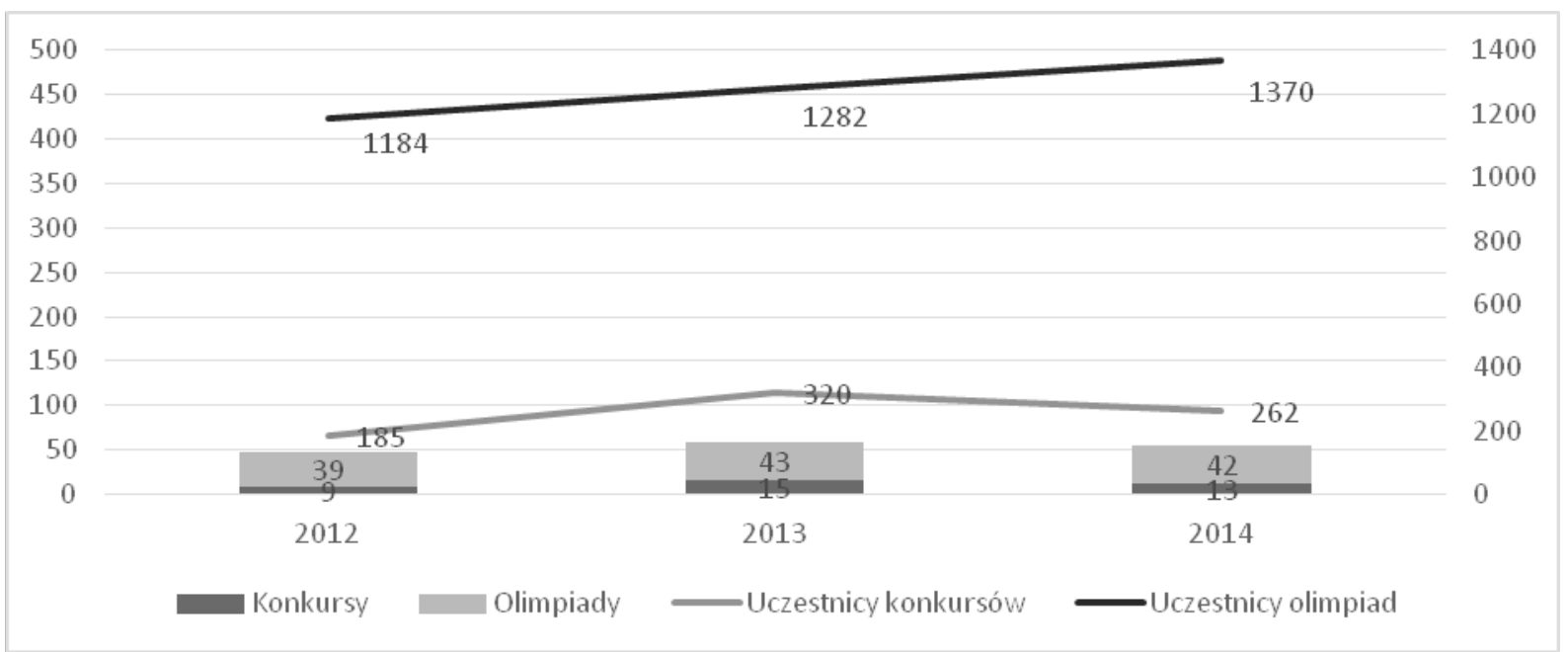

Legend: Konkursy - Competitions; Olimpiady - Contests; Uczestnicy konkursów - Participants of competitions; Uczestnicy olimpiad - Participants of contests

Figure 8. The number of competitions and contests held by the Siedlce Branch of MAAC, as well as the number of their participants over the period of 2012-2014

Rysunek 8. Liczba konkursów i olimpiad oraz liczba osób w nich uczestniczących zrealizowanych przez MODR Oddział Siedlce w latach $2012-2014$

Source: the authors' proprietary elaboration, based on the activity reports of the Siedlce Branch of MAAC for the period of 2012-2014. Źródło: opracowanie własne na podstawie sprawozdań z działalności Oddziału Siedlce za lata 2012-2014.

Apart from educational activities, another important form of activity was individual collaboration with an individual farmer, expressed as the number of advisory services provided. The thematic scope and the summary of figures on the provision of advisory services by the Siedlce Branch of MAAC are presented in Table 3.

Several dozen thousands of advisory services are provided annually by the Siedlce Branch. Statistically, it can be thus assumed that the advisers supplied advisory services to half of the farms existing in this area. Most services were related to area payments, technology of agricultural production, agricultural management schemes, the RDP 2014-2020a and cross-compliance. Farmers also showed considerable interest in advisory services in the technology of animal production, crediting, economic and production consultancy, facilitation of professional start for young farmers, modernisation of farms and LFA areas. During the analysed three-year-long period 1 adviser provided 1270 advisory services. In 2012, one adviser accounted for 425 advisory
Poza działalnością szkoleniową, ważnym działaniem była praca indywidualna z rolnikiem, wyrażająca się ilością udzielonych porad. Zakres tematyczny i zestawienie ilościowe wykonanych porad w MODR Oddział Siedlce w analizowanym okresie przedstawia tabela 3.

W Oddziale Siedlce ogółem udziela się kilkadziesiąt tysięcy porad rocznie. Statystycznie, więc można przyjąć, że doradcy udzielili porad w prawie co drugim istniejącym na tym terenie gospodarstwie rolnym. Najwięcej porad dotyczyło płatności obszarowych, technologii produkcji roślinnej, programów rolnośrodowiskowych, PROW 2014-2020, cross-compliance. Duże zainteresowanie rolników wzbudzały także porady z technologii produkcji zwierzęcej, kredytowania, doradztwa ekonomiczno-produkcyjnego, ułatwiania startu młodym rolnikom, modernizacji gospodarstw rolnych oraz terenów ONW. W analizowanym trzyletnim okresie 1 doradca udzielił 1270 porad. W 2012 roku na doradcę przypadało 425 porad, gdy w 2014 już ponad 485, co stanowi wzrost o ponad $14 \%$. Porównując dane w tabeli 1. i 3. można 
Table 3. The number of advisory services provided by the advisers in the Siedlce Branch of MAAC during the period of $2012-2014$.

Tabela 3. Liczba udzielonych przez doradców porad w MODR Oddział Siedlce w latach 2012 - 2014

\begin{tabular}{|c|c|c|c|c|c|c|c|}
\hline \multirow[t]{2}{*}{$\begin{array}{l}\text { THE THEMATIC SCOPE OF ADVI- } \\
\text { SORY SERVICES/ } \\
\text { ZAKRES TEMATYCZNY PORAD }\end{array}$} & \multicolumn{3}{|c|}{$\begin{array}{c}\text { The number of adviso- } \\
\text { ry services during the } \\
\text { years/ Liczba porad } \\
\text { w latach } \\
\end{array}$} & \multirow[t]{2}{*}{$\begin{array}{l}\text { THE THEMATIC SCOPE OF } \\
\text { ADVISORY SERVICES/ ZAKRES } \\
\text { TEMATYCZNY PORAD }\end{array}$} & \multicolumn{3}{|c|}{$\begin{array}{l}\text { The number of adviso- } \\
\text { ry services during the } \\
\text { years/ } \\
\text { Liczba porad w latach }\end{array}$} \\
\hline & 2012 & 2013 & 2014 & & 2012 & 2013 & 2014 \\
\hline $\begin{array}{l}\text { Area payments/ Płatności obsza- } \\
\text { rowe }\end{array}$ & 4,440 & 4,665 & 4,981 & $\begin{array}{l}\text { Code of Good Agricultural Prac- } \\
\text { tice/ Kodeks Dobrej Praktyki } \\
\text { Rolniczej }\end{array}$ & 199 & 209 & 173 \\
\hline $\begin{array}{l}\text { RDP (Rural Development Program- } \\
\text { me) 2014-2020/ PROW 2014-2020 }\end{array}$ & - & - & 3039 & $\begin{array}{l}\text { Realisation Programmes for APVs } \\
\text { (Areas of Particular Vulnerability) } \\
\text { - (Siedlce Branch and Poświętne } \\
\text { Branch)/ Realizacji Programów } \\
\text { działań dla terenów OSN (O/Siedlce } \\
\text { i O/Poświętne) }\end{array}$ & 112 & 280 & 322 \\
\hline $\begin{array}{l}\text { Facilitation of professional start for } \\
\text { young farmers/ Ułatwianie startu } \\
\text { młodym rolnikom }\end{array}$ & 633 & 625 & 2,435 & Agritourism/ Agroturystyka & 696 & 727 & 648 \\
\hline $\begin{array}{l}\text { Structural pensions/ Renty struk- } \\
\text { turalne }\end{array}$ & 148 & 89 & 32 & $\begin{array}{l}\text { Healthy food production/ Produk- } \\
\text { cja zdrowej żywności }\end{array}$ & 217 & 256 & 359 \\
\hline $\begin{array}{l}\text { Semi-subsistence farms/ Gospo- } \\
\text { darstwa niskotowarowe }\end{array}$ & 43 & 92 & 127 & $\begin{array}{l}\text { Health prophylaxis in rural areas/ } \\
\text { Profilaktyka zdrowotna na wsi }\end{array}$ & 243 & 201 & 245 \\
\hline $\begin{array}{l}\text { Modernisation of farms/ Moderni- } \\
\text { zacja gospodarstw rolnych }\end{array}$ & 1175 & 1115 & 1433 & $\begin{array}{l}\text { Implementation of GMP, GHP and } \\
\text { HACCP rules/ Wdrażania zasad } \\
\text { GMP, GHP i HACCP }\end{array}$ & 138 & 51 & 108 \\
\hline $\begin{array}{l}\text { Food quality systems - regional } \\
\text { and traditional products/ Systemy } \\
\text { jakości żywności - produkt regio- } \\
\text { nalny i tradycyjny }\end{array}$ & 405 & 454 & 491 & $\begin{array}{l}\text { Promotion of the positive image of } \\
\text { the countryside and farmstead/ } \\
\text { Promocja pozytywnego wizerunku } \\
\text { wsi i gospodarstwa }\end{array}$ & 105 & 82 & 262 \\
\hline $\begin{array}{l}\text { Food quality systems -ecological } \\
\text { production/ Systemy jakości żyw- } \\
\text { ności -produkcja ekologiczna }\end{array}$ & 258 & 223 & 266 & $\begin{array}{l}\text { Rational management of a rural } \\
\text { farmstead/ Racjonalne zagospoda- } \\
\text { rowanie zagrody wiejskiej }\end{array}$ & 524 & 597 & 623 \\
\hline $\begin{array}{l}\text { Food quality systems -integrated } \\
\text { production - IP/ Systemy jakości } \\
\text { żywności -produkcja integrowana } \\
\text { - IP }\end{array}$ & 148 & 245 & 266 & $\begin{array}{l}\text { Cultivating traditions, preservation } \\
\text { of cultural heritage/ Kultywowanie } \\
\text { tradycji, zachowanie dziedzictwa } \\
\text { kulturowego }\end{array}$ & 407 & 563 & 582 \\
\hline $\begin{array}{l}\text { Increasing the added value of the } \\
\text { basic agricultural and forestry } \\
\text { production/ Zwiększanie wartości } \\
\text { dodanej podstawowej produkcji } \\
\text { rolnej i leśnej }\end{array}$ & 7 & 8 & 8 & $\begin{array}{l}\text { Groups of agricultural producers/ } \\
\text { Grupy producentów rolnych }\end{array}$ & 1068 & 805 & 754 \\
\hline $\begin{array}{l}\text { Informational and promotional } \\
\text { activities/ Działania informacyjne } \\
\text { i promocyjne }\end{array}$ & 336 & 216 & 85 & $\begin{array}{l}\text { Technology of plant production/ } \\
\text { Technologia produkcji roślinnej }\end{array}$ & 3816 & 4330 & 3822 \\
\hline $\begin{array}{l}\text { Areas classified as LFA (Less Favo- } \\
\text { ured Areas)/ Tereny ONW }\end{array}$ & 1119 & 1031 & 1092 & $\begin{array}{l}\text { Technology of horticultural pro- } \\
\text { duction/ Technologia produkcji } \\
\text { ogrodniczej }\end{array}$ & 796 & 728 & 729 \\
\hline $\begin{array}{l}\text { Environmental Management } \\
\text { Scheme 2004-2006/ Program rol- } \\
\text { nośrodowiskowy 2004-2006 }\end{array}$ & 157 & 93 & 17 & $\begin{array}{l}\text { Technology of animal production/ } \\
\text { Technologia produkcja zwierzęcej }\end{array}$ & 1809 & 2194 & 1785 \\
\hline $\begin{array}{l}\text { Reforestation of agricultural land/ } \\
\text { Zalesianie gruntów }\end{array}$ & 501 & 478 & 522 & $\begin{array}{l}\text { Insurance in agriculture/ Ubezpie- } \\
\text { czenia w rolnictwie }\end{array}$ & 682 & 659 & 487 \\
\hline $\begin{array}{l}\text { Restoring the potential of forestry } \\
\text { production/ Odtwarzanie poten- } \\
\text { cjału produkcji leśnej }\end{array}$ & 63 & 97 & 45 & Crediting/ Kredytowanie & 1312 & 1385 & 869 \\
\hline $\begin{array}{l}\text { Diversification towards non-agri- } \\
\text { cultural activity/ Różnicowanie } \\
\text { w kierunku działalności nierolni- } \\
\text { czej }\end{array}$ & 786 & 467 & 287 & $\begin{array}{l}\text { Purchase of production resources } \\
\text { and nursery stock/ Zakup środków } \\
\text { produkcji oraz materiału szkółkar- } \\
\text { skiego }\end{array}$ & 337 & 495 & 424 \\
\hline $\begin{array}{l}\text { Creation and development of micro- } \\
\text {-enterprises/ Tworzenie i rozwój } \\
\text { mikroprzedsiębiorstw }\end{array}$ & 612 & 677 & 159 & $\begin{array}{l}\text { Taxation of agriculture/ Podatki } \\
\text { w rolnictwie }\end{array}$ & 551 & 571 & 475 \\
\hline
\end{tabular}




\begin{tabular}{|c|c|c|c|c|c|c|c|}
\hline $\begin{array}{l}\text { Basic services for rural economy } \\
\text { and population/ Podstawowe } \\
\text { usługi dla gospodarki i ludności } \\
\text { wiejskiej }\end{array}$ & 24 & 17 & 16 & $\begin{array}{l}\text { Economic and production consul- } \\
\text { ting (profitability, calculations, } \\
\text { pricing)/ Doradztwo ekonomicz- } \\
\text { no-produkcyjne (opłacalność, } \\
\text { kalkulacje, ceny) }\end{array}$ & 1052 & 1089 & 1037 \\
\hline $\begin{array}{l}\text { Restoration and development of the } \\
\text { countryside/ Odnowa i rozwój wsi }\end{array}$ & 122 & 56 & 32 & $\begin{array}{l}\text { Ecological agriculture/ Rolnictwo } \\
\text { ekologiczne }\end{array}$ & 932 & 940 & 741 \\
\hline $\begin{array}{l}\text { Environmental Management } \\
\text { Scheme 2007-2013/ Program rol- } \\
\text { nośrodowiskowy 2007-2013 }\end{array}$ & 4431 & 4082 & 2869 & $\begin{array}{l}\text { The network of Natura 2000/ Sieć } \\
\text { Natura } 2000\end{array}$ & 346 & 424 & 331 \\
\hline Leader/ Leader & 115 & 187 & 122 & $\begin{array}{l}\text { Cross-compliance/ Cross-com- } \\
\text { pliance }\end{array}$ & 3567 & 2458 & 2187 \\
\hline $\begin{array}{l}\text { Information about MACC (e.g. for } \\
\text { students)/ Informacja o MODR (np. } \\
\text { dla studentów) }\end{array}$ & 296 & 244 & 155 & $\begin{array}{l}\text { Renewable energy/ Energetyka } \\
\text { odnawialna }\end{array}$ & 534 & 411 & 311 \\
\hline $\begin{array}{l}\text { Information about participation in } \\
\text { training sessions, demonstrations, } \\
\text { etc./ Informacja o uczestnictwie } \\
\text { w szkoleniach, pokazach, itp. }\end{array}$ & 678 & 546 & 416 & $\begin{array}{l}\text { Reduction of pollution generated } \\
\text { by agriculture/ Ograniczania za- } \\
\text { nieczyszczeń pochodzenia rolni- } \\
\text { czego }\end{array}$ & 128 & 108 & 137 \\
\hline ASIF/ KRUS & 343 & 274 & 326 & $\begin{array}{l}\text { Protection of the environment/ } \\
\text { Ochrona środowiska }\end{array}$ & 836 & 861 & 655 \\
\hline $\begin{array}{l}\text { Propagation of knowledge about le- } \\
\text { gal regulations: Animal Protection } \\
\text { Law/ Upowszechnianie przepisów: } \\
\text { Ustawy o Ochronie Zwierząt }\end{array}$ & 338 & 577 & 414 & $\begin{array}{l}\text { Mechanisation of agriculture and } \\
\text { livestock housing/ Mechanizacja } \\
\text { rolnictwa i budownictwa inwen- } \\
\text { tarskiego }\end{array}$ & 378 & 317 & 354 \\
\hline $\begin{array}{l}\text { Agricultural qualifications / Kwali- } \\
\text { fikacje rolnicze }\end{array}$ & 284 & 322 & 497 & $\begin{array}{l}\text { Propagation of educational farms/ } \\
\text { Upowszechnianie zagród eduka- } \\
\text { cyjnych }\end{array}$ & - & 129 & 318 \\
\hline $\begin{array}{l}\text { Restoring the potential of agri- } \\
\text { cultural production, destroyed as } \\
\text { a result of natural disasters and } \\
\text { catastrophes and implementing } \\
\text { appropriate prevention measures/ } \\
\text { Przywracanie potencjału produk- } \\
\text { cji rolnej zniszczonego w wyniku } \\
\text { klęsk żywiołowych i katastrof } \\
\text { oraz wprowadzenie odpowiednich } \\
\text { środków zapobiegawczych }\end{array}$ & - & - & 270 & $\begin{array}{l}\text { Improving and developing infra- } \\
\text { structure associated with the } \\
\text { development and adaptation of } \\
\text { agriculture and forestry/ Poprawa } \\
\text { i rozwijanie infrastruktury zwią- } \\
\text { zanej z rozwojem i dostosowaniem } \\
\text { rolnictwa i leśnictwa }\end{array}$ & 13 & 13 & 8 \\
\hline $\begin{array}{l}\text { Environmental and climatic } \\
\text { management measures/ Działania } \\
\text { rolno-środowiskowo-klimatyczne }\end{array}$ & - & - & 931 & \begin{tabular}{|l} 
Ecological agriculture - RDP \\
2014-2020/ Rolnictwo ekologiczne \\
PROW 2014-2020
\end{tabular} & - & - & 541 \\
\hline Soil testing/ Badania gleby & - & - & 388 & $\begin{array}{l}\text { Integrated pest management/ Inte- } \\
\text { growana ochrona roślin }\end{array}$ & - & - & 752 \\
\hline
\end{tabular}

Source: the authors' own elaboration based on reports of the activities of the Siedlce Branch of MAAC during the years $2012-2014$. Źródło: zestawienie własne na podstawie sprawozdań z działalności MODR Oddział Siedlce za lata 2012-2014.

services, while in 2014 more than 485 - it is an increase of over $14 \%$. Comparing the data in Table 1 and 3 , it can be concluded that reducing the number of requests and paid services provided by advisers $(-20 \%)$ was compensated for by an increase in the number of provided services $(+14 \%)$.

\section{Conclusions}

The activity of the Siedlce Branch, both the commercial and the statutory one during the period of 2012 - 2014 commanded the interest of farmers, which is confirmed by the analysis of the services performed by the advisers. The number of paid services in application preparation, due to increasing competition, decreases year over year, while the number of stationary and field training sessions, wyciągnąć wniosek, że zmniejszanie liczby wykonywanych przez doradców wniosków i usług płatnych (-20\%) było rekompensowane zwiększeniem liczby udzielanych porad (+14\%).

\section{Podsumowanie}

Działalność Oddziału Siedlce, zarówna ta komercyjna jak i statutowa w okresie 2012 - 2014 cieszyła się zainteresowaniem rolników, co potwierdza przeprowadzona analiza wykonanych przez doradców usług. Liczba wykonanych wniosków płatnych z uwagi na wzrastającą konkurencję z roku na rok spada, natomiast liczba szkoleń stacjonarnych i wyjazdowych, pokazów, konferencji, konkursów, 
shows, conferences, competitions, contests and advisory services remains at a similar level. It can therefore be concluded that agricultural advisory services fulfil a very important role in the adaptation of farms to changing environmental conditions. Nowadays, in the era of globalisation and integration farmers face new challenges, which would be difficult to handle without an efficient agricultural advisory system. The activity of the advisers from the Siedlce Branch of the Mazovian Agricultural Advisory Centre in Warsaw shows great interest on the part of farmers as regards the presented offer. Such a large number of diverse activities and services requires institutions to possess a properly coordinated organisation, acquire new, updated information, process it and then transfer it to its final recipient - the farmer. olimpiad oraz porad utrzymuje się na podobnym poziomie. Można zatem wnioskować, że doradztwo rolnicze spełnia bardzo ważną funkcję $\mathrm{w}$ dostosowaniu gospodarstw do zmieniających się warunków otoczenia. Zwłaszcza w obecnych czasach, w dobie globalizacji i integracji rolnicy stają przed nowymi wyzwaniami, którym trudno byłoby sprostać bez sprawnego systemu doradztwa rolniczego. Działania doradców Oddziału Siedlce Mazowieckiego Ośrodka Doradztwa Rolniczego w Warszawie wskazuja na duże zainteresowanie rolników przedstawianą ofertą. Tak duża liczba różnorodnych działań i usług wymaga od instytucji odpowiednio skoordynowanej organizacji, pozyskiwania nowych, aktualnych informacji, ich przetwarzania i przekazywania w teren do finalnego jej odbiorcy - rolnika.

\section{References/ Literatura:}

1. Firlej K., Rydz A. (2012), System doradztwa rolniczego w Polsce oraz jego wykorzystanie w ramach działania 114 PROW $2007-$ 2013. Roczniki Ekonomiczne, nr 5, s. 199-222.

2. Grzelak A. (2009), Efektywność powiq̨zań gospodarstw rolnych z otoczeniem w świetle doświadczeń Polski po roku 1990. Roczniki Ekonomiczne, nr 2, s. 57-74.

3. Kania J. (2006a), Przyszłość doradztwa rolniczego w Polsce. Zagadnienia Doradztwa Rolniczego, nr 1, s. 63-74.

4. Kania J. (2006b), Znaczenie doradztwa w rozwoju rolnictwa i obszarów wiejskich, W: Miejsce doradztwa we wspieraniu rozwoju rolnictwa i wsi na Kujawach i Pomorzu. Materiały konferencyjne. Minikowo, s. 22-35.

5. Kania J. (2007), Doradztwo rolnicze w Polsce w świetle potrzeb i doświadczeń zagranicznych. Rozprawy, z. 318, s. 201.

6. Kujawiński W. (2003), Nowy zawód - doradca rolniczy. Zagadnienia Doradztwa Rolniczego, nr 1/2, s. 15-27.

7. Matuszak E. (2002), Doradztwo rolnicze w kontekście integracji z Uniq Europejską. Zagadnienia Doradztwa Rolniczego, nr 3/4, s. 17-23.

8. Nowogródzka T. (2009), Wpływ rozwoju regionalnego na zmiany organizacji doradztwa rolniczego w Polsce. Zeszyty Naukowe Akademii Podlaskiej w Siedlcach, nr. 83, s. 111-120.

9. Regulamin organizacyjny Mazowieckiego Ośrodka Doradztwa Rolniczego w Warszawie. Załącznik do uchwały Nr 109/10 Sejmiku Województwa Mazowieckiego z dnia 5 lipca 2010 roku.

10. Sprawozdanie z realizacji programu działalności za 2012 r. MODR Oddział Siedlce, Siedlce, styczeń 2013r. (materiał powielany).

11. Sprawozdanie z realizacji programu działalności za 2013 r. MODR Oddział Siedlce, Siedlce, styczeń 2014r. (materiał powielany).

12. Sprawozdanie z realizacji programu działalności za 2014 r. MODR Oddział Siedlce, Siedlce, styczeń 2015r. (materiał powielany).

13. Staniszewski J. (2014), Doradztwo rolnicze, jako element instytucjonalnego otoczenia polskiej wsi. Roczniki Ekonomiczne, nr 7, s. 266-276.

14. Ustawa o jednostkach doradztwa rolniczego z dn. 22 października 2004 r. (Dz.U. z 2013 poz. 474 z późn. zm.). 